\title{
Emerging contaminants in raw water supply in the east of Tehran
}

\section{Zarei ${ }^{1}$, R Moogouei ${ }^{2 *}$, M Tbari $^{3}$}

${ }^{1}$ MSc Student, Department of Food Science and Engineering, Islamic Azad University, North Tehran Branch, Tehran, Iran.

${ }^{2}$ Department of Environmental Planning, Management and Education, Islamic Azad University, North Tehran Branch, Tehran, Iran.

${ }^{3}$ Department of Food Science and Engineering, Islamic Azad University, North Tehran Branch, Tehran, Iran.

Received: June 2017

\begin{abstract}
Emerging contaminant in drinking water has created concerns among public, water supplier and government. Pharmaceutical in water and food even in low concentration have shown potential risks to human. Acetaminophen and ibuprofen are among a set of the most prescribed drugs in the world. In this study raw water and treated drinking water from Latyan drinking water treatment facilities were analyzed to determine possible concentration of acetaminophen and ibuprofen in water. All the

In the case of ibuprofen the only observed concentration was equal to $11.49 \pm 0.33$ in the Latyan Dam Lake. No concentration of acetaminophen and ibuprofen was detected in drinking water samples gathered after treatment process. Why pharmaceuticals were known as indicators for controlling the quality of raw water and the treatment efficiency in the drinking water treatment facilities, ground water and treated water of this area are safe with no detection of acetaminophen and ibuprofen.
\end{abstract} data were subjected to analysis of variance to consider significance of differences. Furthermore mean comparison between data was calculated using Duncan test. Presence of acetaminophen in the ground water resources was not reported. While in the Jajrood river and Latyan Dam Lake the concentration of acetaminophen were $2.16 \pm 0.09$ and $9.17 \pm 0.18 \eta \mathrm{g} \mathrm{L}^{-1}$ respectively.

Correspondence: R Moogouei. Department of Environmental Planning, Management and Education, Islamic Azad University, North Tehran Branch, Tehran, Iran. (e-mal: r_moogoui@iau-tnb.ac.ir).
Accepted: September 2017

Keywords: Raw water, Acetaminophen, Ibuprofen, Contamination.

\section{Introduction}

Pharmaceutical compounds enter to the environment via discharge of treated wastewater, septic tanks, landfills, sewer lines, animal waste runoff and manure fertilizers (Fram \& Belitz 2011). Many of these pharmaceuticals have been recognized to survive in wastewater treatment and be discharged to surface and groundwater. 
Moreover pharmaceutical in drinking water has created concerns among public, water supplier and government. Pharmaceutical in water and food even in low concentration have shown potential risks to human. Emission of pollutants from sewage to drinking water increased risk of cancers in human (LuqueEspinar, Navas, Chica-Olmo, CantareroMalagón \& Chica-Rivas 2015). In many countries occurrence and fate of pharmaceutical in raw water and in food products remains unknown. However the presence of this pollutants and their by-product in drinking water must be considered even where their concentrations are very low (Mompelat, Le Bot \& Thomas (2009); Caban, Lis, Kumirska \& Stepnowski, (2015)). Moreover from many aspects, pharmaceutical pollution of drinking water can be considered. Disinfection of drinking water in treatment process produce byproducts which have been proven to be more toxic than their parent compounds. Postigo \& Richardson (2014) and Fram \& Belitz (2011) have reported that concentration of pharmaceutical compound in wastewater after treatment process are less than $1 \mu \mathrm{g} \mathrm{L}^{-1}$ while in many cases pharmaceutical concentrations are detected about several $\mathrm{mg} \mathrm{L}^{-1}$ specially in effluent from treatment facilities that receive waste from pharmaceutical manufacturing (Phillips, Smith, Kolpin, Zaugg, Buxton \& Furlong, (2010); Fram \& Belitz (2011)) . In the study carried out by Padhye, Yao, Kung'u \& Huang (2014) average total pharmaceutical and personal care products and endocrine disrupting chemicals concentration in the surface water source was around $360 \mathrm{ng} \mathrm{L}^{-1}$. Furthermore In the study carried out by Lin, Yu \& Chen (2016) after a series of treatment processes, indomethacin, caffeine and sulfamethoxazole were found in effluent, at concentrations less than $2 \mathrm{ng} \mathrm{L}^{-1}$ Luque-Espinar et al. (2015) have found that the concentration of paracetamol in rivers and channels was up to $34.3 \mu \mathrm{g} \mathrm{L}^{-1}$. Because most of the drinking water treatment facillities all over the world are not specifically designed to remove pharmaceutical active compounds, thereby these compounds are found in drinking water (Vergili 2013). There are presently no regulations or drinking water directives for pharmaceutical products. Rosal, Antonio Rodríguez, Perdigón-Melón, Petre, García-Calvo, José Gómez, Agüera, Amadeo \&Fernández-Alba (2010) have reported that acetaminophen is among the main individual pollutants usually found in concentrations

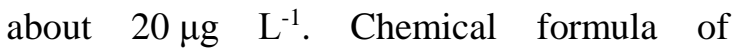
acetaminophen is shown in Figure 1.

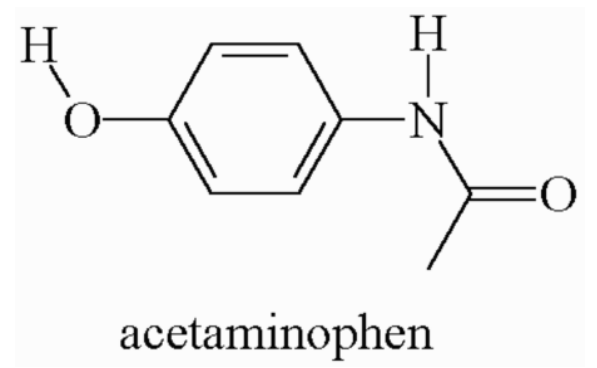

Figure 1. Acetaminophen

Ibuprofen is an optically active compound. Ibuprofen is found in some water resources and is toxic for human, flora and funa. These compounds are persistent during the treatment process of drinking water. Chemical formula of ibuprofen is shown in Figure 2. The objective of this study is to evaluate the concentration of acetaminophen and ibuprofen in untreated 
groundwater, surface water and treated water

used for public drinking-water supplies.<smiles>CC(C)Cc1ccc(C(C)C(=O)O)cc1</smiles>

Figure 2. Ibuprofen

\section{Materials and Methods}

\section{Study area}

Latyan Dam on the Jajrood river is used for drinking water supply in Tehran (Figure 3). About $30 \%$ of drinking water of Tehran is supplied by this dam. Latyan dam lake is used for drinking water supply of east part of Tehran (Figure 4).

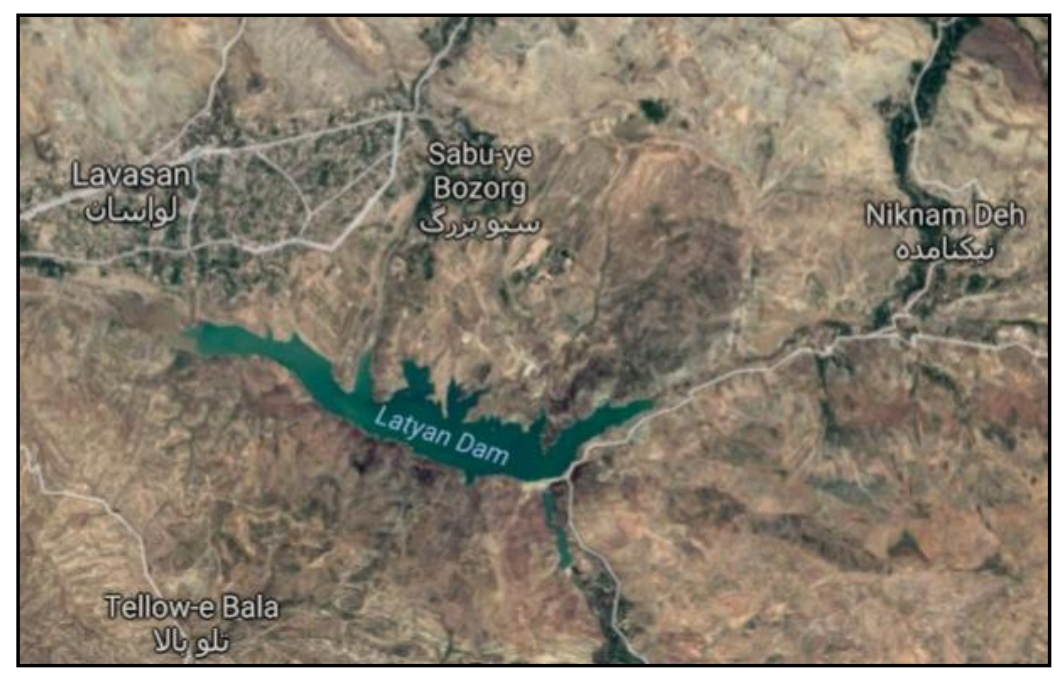

Figure 3. Map of Latyan area

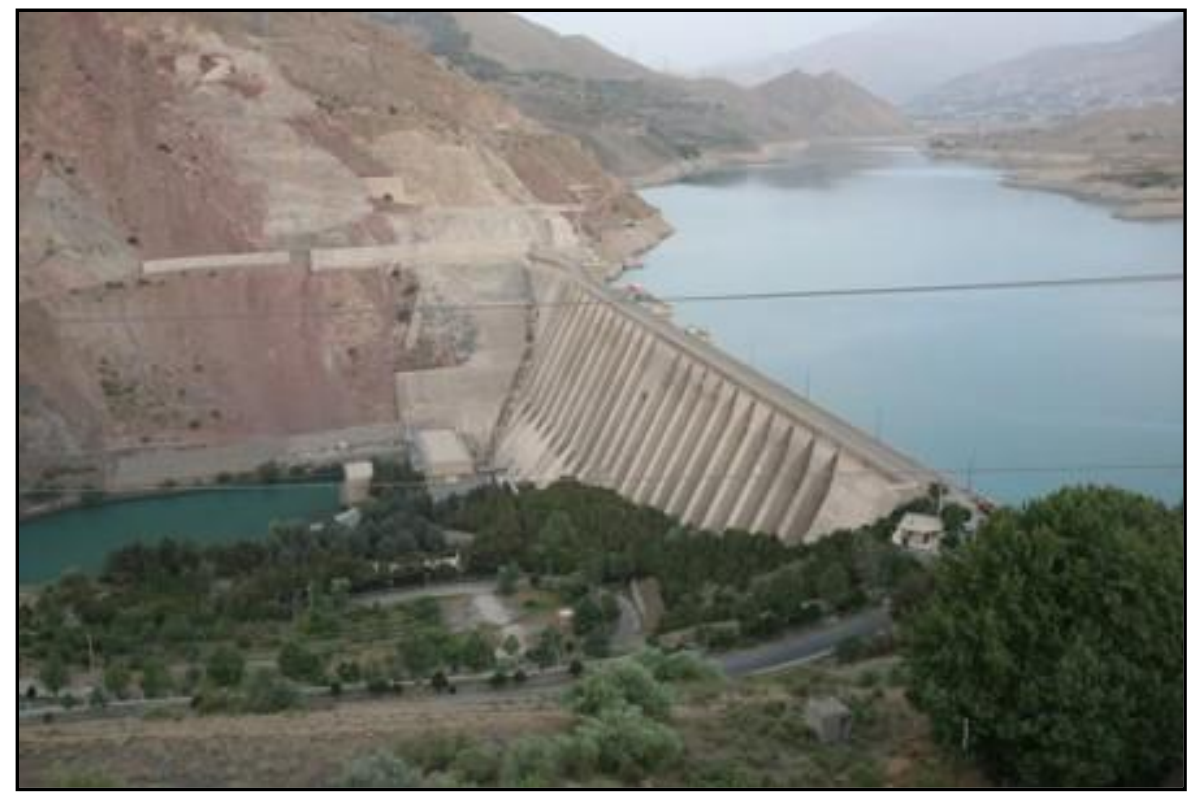

Figure 4. Latyan Dam Lake 


\section{Acetaminophen and ibuprofen concentrations}

Five sampling stations in this area were selected (Figure 5). These stations located in springs, river, Dam lake and one station after treatment facilities. All the samples were gathered in summer 2016 in randomized design. To avoid the effect of light, samples were gathered in dark sterile bottles. All the samples were analyzed for acetaminophen and ibuprofen concentrations in $\mu \mathrm{g} \quad \mathrm{L}^{-1}$ using High Performance Liquid Chromatography (HPLC). This is a separation technique that relies on relative motion of two phases. In liquid chromatography, motion phase is liquid. In gas chromatography, motion phase is gas. Extraction is the first step. For this purpose an appropriate solvent is added to desired material. In this study, liquid-liquid extraction is used. Because the solvent used for separation of acetaminophen and ibuprofen was liquid. The solvent used must have the following two characteristics: a) analyte should not solve in it and the solvent do not solve in matrix. The portion of solvent to sample was 1 to 10 . The prepared sample is placed inside the mixer. Until water and solvent completely be mixed with each other. Then analyte be extracted. In the next step, material is placed in the decanter's funnel. Using the end valve, desired section is separated and considered. When analyte is injected into the device, chromatogram indicator is generated and identified by detector. To determine the concentration of acetaminophen and ibuprofen in extract solvent, first a $100 \%$ acetaminophen and ibuprofen solvent is prepared (CRM). Then CRM is injected. After that a graph with a specific level and pic is produced. Then analyte is injected and again a specific graph is produced. Two graph with one pic are compared. After obtaining desired pic, they are compared with CRM pic and then concentrations of acetaminophen and ibuprofen are determined.

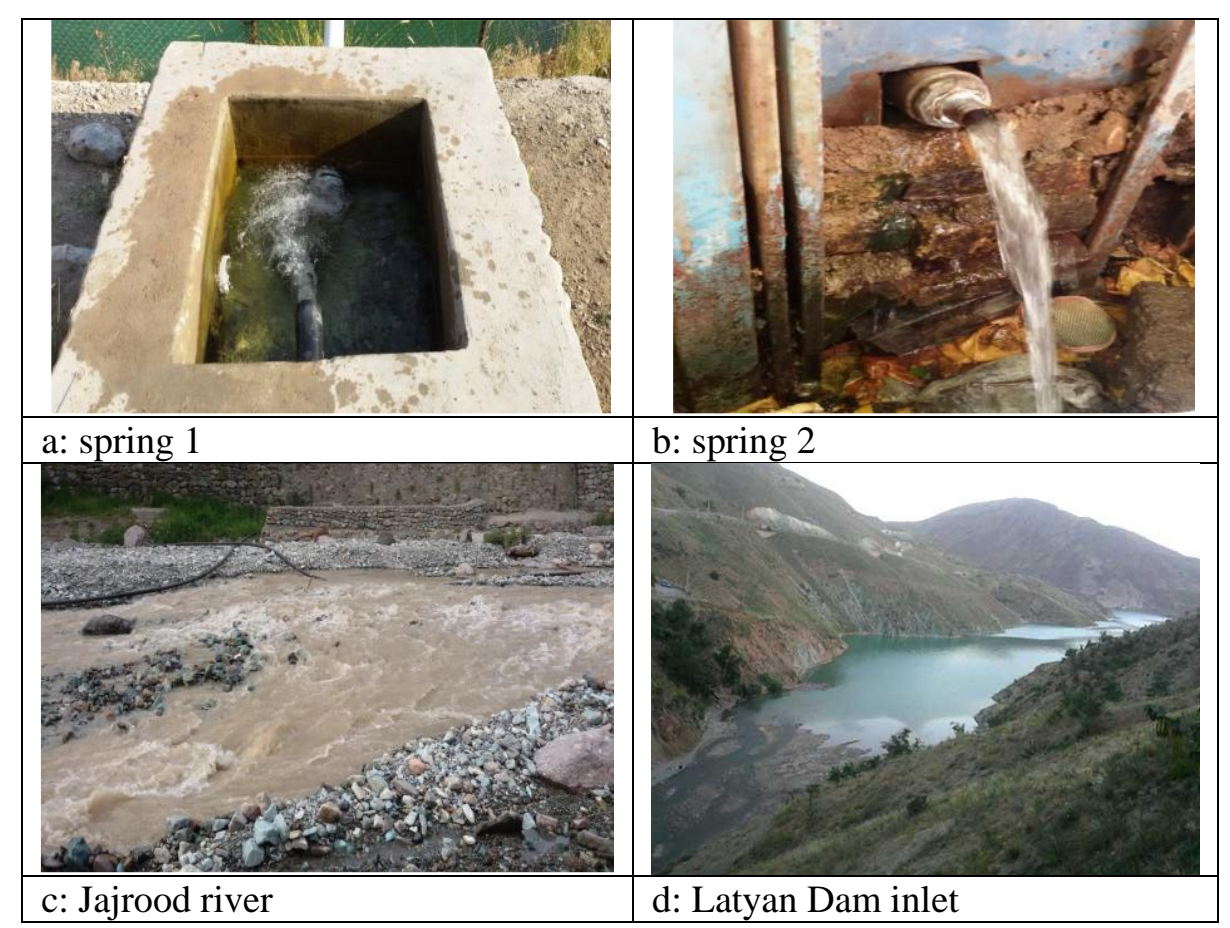

Figure 5. Sampling stations in springs, river and dam lake. 


\section{Statistical analyses}

All the experiments were performed in triplicate and the statistical analysis was performed using SPSS software package. To approve the variability of results, all the data were subjected to analysis of variance to consider the significance differences. Furthermore means comparison between data was obtain using Duncan test.

\section{Results}

Concentrations of acetaminophen and ibuprofen ( $\eta \mathrm{g} \mathrm{L}^{-1}$ ) in drinking water supply of east part of Tehran is shown in Table 1. Moreover ANOVA analyses of acetaminophen and ibuprofen concentration data is shown in Table 2.

Table 1. Concentrations of Acetaminophen and Ibuprofen in $\eta \mathrm{g} \mathrm{L}^{-1}$ in drinking water supply of east part of Tehran. All data are mean of three replicate \pm SD. (LOD: limit of detection; nd: not detectable). $\mathrm{P}<0.05$. There is no significant differences between data

\begin{tabular}{llllll}
\hline & $\begin{array}{l}\text { Station 1 } \\
\text { After treatment facilities }\end{array}$ & $\begin{array}{l}\text { Station 2 } \\
\text { Dam Lake }\end{array}$ & $\begin{array}{l}\text { Station 3 } \\
\text { Rasnan Spring }\end{array}$ & $\begin{array}{l}\text { Station 4 } \\
\text { Jajrood river }\end{array}$ & $\begin{array}{l}\text { Station 5 } \\
\text { Afjeh spring }\end{array}$ \\
\cline { 2 - 6 } Acetaminophen & nd & $9.17 \pm 0.18$ & $<$ LOD & $2.16 \pm 0.09$ & $<$ LOD \\
\hline Iboprufen & nd & $11.49 \pm 0.33$ & $<$ LOD & $<$ LOD & $<$ LOD \\
\hline
\end{tabular}

Table 2. ANOVA analyses of acetaminophen and ibuprofen concentrations in sampling stations

\begin{tabular}{llllll}
\hline & Sum of Squares & df & Mean Square & F & Sig. \\
\hline Acetaminophen & 189.378 & 4 & 47.345 & 5587.4 & 0.000 \\
\hline Ibuprofen & 317.216 & 4 & 79.30 & 3577.6 & 0.000 \\
\hline
\end{tabular}

\section{Discussion}

During last two decades, globally increasing consumption of chemicals compounds and detection of emerging contaminants in aquatic

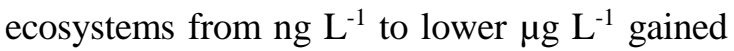
much attention (Gabarrón, Gernjak, Valero, Barceló, Petrovic \& Rodríguez-Roda 2017). Trace concentrations of pharmaceutical compounds have been detected in groundwater, surface water and drinking water (Bruce, Pleus \& Snyder (2010); Fram \& Belitz, (2011)). Among all emerging contaminants in raw water, pharmaceutical products and residues are of great important. (Mompelat et al. 2009). There are no regulation for drinking water including acetaminophen and ibuprofen removal, assessing this products in water has significant role in reduction of human health risks. Degradation of acetaminophen with initial concentration of 100 $\mu \mathrm{g} \mathrm{\textrm {L } ^ { - 1 }}$ was considered in a study carried by (Klamerth, Rizzo, Malato, Maldonado, Agüera \& Fernández-Alba 2010). Degradation rate is totally independent of $\mathrm{pH}$, the initial $\mathrm{H}_{2} \mathrm{O}_{2}$ concentration and also the type of acid used for release of hydroxyl radicals scavengers. This study showed that degradation of acetaminophen in waste water led to toxicity increase (Klamerth et al. 2010). Moreover Vergili (2013) has found the presence of ibuprofen in drinking water resources. In the study carried out by LuqueEspinar et al. (2015) ibuprofen was detected 
several times with concentration ranges from 5.3 to $20.8 \mu \mathrm{g} \quad \mathrm{L}^{-1}$. In the present study acetaminophen concentration in Latyan Dam Lake was $9.17 \pm 0.18 \eta g \mathrm{~L}^{1}$. And in the case of ibuprofen the concentration was equal to $11.49 \pm$ 0.33 . No presence of acetaminophen and ibuprofen was detected in drinking water samples gathered after treatment facilities. There was no correlation between acetaminophen concentration in the source water and in the drinking water over the one year study period. Pharmaceuticals were known as indicators for controlling the quality of raw water and the treatment efficiency in the drinking water treatment facilities (Gaffney, Almeida, Rodrigues, Ferreira, Benoliel \& Vale Cardoso 2015). As a result, ground water of this area are sate with no detection of acetaminophen and ibuprofen.

\section{References}

Bruce GM., Pleus RC., Snyder SA. (2010) Toxicological relevance of pharmaceuticals in drinking water. Environ Sci Technol;44:561926.

Caban M., Lis E., Kumirska J., Stepnowski P. (2015) Determination of pharmaceutical residues in drinking water in Poland using a new SPE-GC-MS (SIM) method based on Speedisk extraction disks and DIMETRIS derivatization. Science of The Total Environment, Volume 538, Pages 402-411.

Farm M. S. \& Belitz K. (2011) Occurrence and concentrations of pharmaceutical compounds in groundwater used for public drinking-water supply in California. Science of the Total Environment, Volume 409, Issue 18, Pages 3409-3417.

Gaffney V., Almeida C. M.M., Rodrigues A., Ferreira E., Benoliel M, Vale Cardoso V. (2015) Occurrence of pharmaceuticals in a water supply system and related human health risk assessment, Water Research, Volume 72, Pages 199-208.

Gabarrón S., Gernjak W., Valero V., Barceló A., Petrovic M., Rodríguez-Roda, I. (2017) Evaluation of emerging contaminants in a drinking water treatment facilities using electrodialysis reversal technology, Journal of Hazardous Materials, Volume 309, Pages 192201.

Klamerth N, Rizzo L, Malato S, Maldonado M.I. , Agüera A., Fernández-Alba A.R. (2010) Degradation of fifteen emerging contaminants at $\mu \mathrm{g} \mathrm{L}^{-1}$ initial concentrations by mild solar photo-Fenton in MWTP effluents, Water Research, Volume 44, Issue 2, Pages 545-554.

Lin T., Yu S., Chen W. (2016) Occurrence, removal and risk assessment of pharmaceutical and personal care products (PPCPs) in an advanced drinking water treatment facilities (ADWTP) around Taihu Lake in China Chemosphere, Volume 152, Pages 1-9.

Lokesh P. Padhye, Hong Yao, Francis T. Kung'u, Ching-Hua Huang (2014) Year-long evaluation on the occurrence and fate of pharmaceuticals, personal care products, and endocrine disrupting chemicals in an urban 
drinking water treatment facilities Water

Research, Volume 51, Pages 266-276.

Luque-Espinar J.A., Navas N., Chica-Olmo M., Cantarero-Malagón S., Chica-Rivas L. (2015) Seasonal occurrence and distribution of a group of ECs in the water resources of Granada city metropolitan areas (South of Spain): Pollution of raw drinking water Journal of Hydrology, Volume 531, Part 3, Pages 612-625.

Mompelat S., Le Bot B., Thomas O. (2009) Occurrence and fate of pharmaceutical products and by-products, from resource to drinking water. Environment International, Volume 35, Issue 5, Pages 803-814.

Phillips PJ, Smith SG, Kolpin DW, Zaugg SD, Buxton HT, Furlong ET (2010) Pharmaceutical formulation facilities as sources of opioids and other pharmaceuticals to wastewater treatment plant effluents. Environ Sci Technol; 44:4910-
6.

Postigo C. \& Richardson S (2014) Transformation of pharmaceuticals during oxidation/disinfection processes in drinking water treatment. Journal of Hazardous Materials, Volume 279, 30, Pages 461-475.

Rosal R., Antonio Rodríguez A., PerdigónMelón J., Petre A., García-Calvo E., José Gómez M., Agüera A., Amadeo R. FernándezAlba A. R. (2010) Occurrence of emerging pollutants in urban wastewater and their removal through biological treatment followed by ozonation, Water Research, Volume 44, Issue 2, Pages 578-588.

Vergili I . (2013) Application of nanofiltration for the removal of carbamazepine, diclofenac and ibuprofen from drinking water sources Istanbul University, Journal of Environmental Management, Volume 127, Pages 177-187. 


\title{
آلودَى هاى نوظهور در منابع آب خام شرق تهران
}

\author{
مريم زارعى '، ركسانا موكويى" "، مهسا تبرى" \\ ' دانشجوى كارشناسى ارشد، گروه علوم و مهندسى صنايع غذائى، دانشَاه آزاد اسلامى واحد تهران شمال، تهران، ايران. \\ r ك كروه برنامه ريزى، مديريت و آموزش محيط زيست، دانشخاه آزاد اسلامى واحد تهران شمال، تهران، ايران. \\ r "َروه علوم و مهندسى صنايع غذائى، دانشخاه آزاد اسلامى واحد تهران شمال، تهران، ايران.
}

جكيده

بروز آلودگىهاى نوظهور آب آشاميدنى، در دولت، افكار عمومى و تأمين كنندًان آب آشاميدنى ايجاد نكرانى نموده است. بروز تركيبات دارويى در آب و غذا براى سلامتى انسان ايجاد ريسك مىنمايد. استامينوفن و ايبويروفن جزء سرى داروهايى هستند كه در سطح جهانى، زياد تجويز مىشوند. در اين مطالعه آب خام و آب آشاميدنى منطقه سد لتيان از نظر وجود استامينوفن و ايبويروفن مورد بررسى قرار كرفته است. سيس دادههاى مورد آناليز واريانس و تفاوت معنادارى قرار كرفته و با استفاده از تست دانكن مورد مقايسه ميانكين قرار كرفته است. نتايج حاصله نشان داد كه استامينوفن در منابع آب زيرزمينى وجود ندارد. اما در

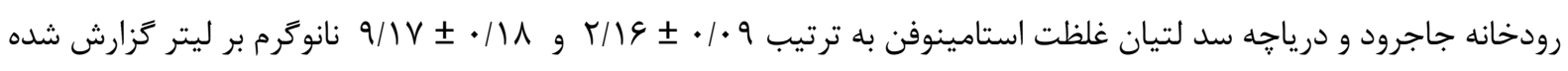

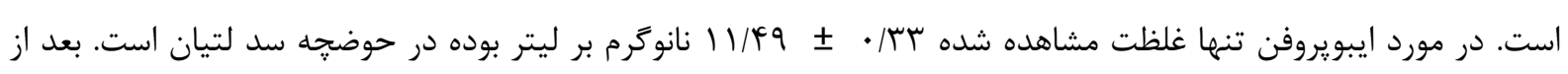
عمليات تصفيه آب آشاميدنى، استامينوفن و ايبويروفن در نمونههاى جمع آورى شده مشاهده نشده است. نتايج اين تحقيق نشان مىدهد، جون تركيبات داروئى شاخصهاى كنترل كيفيت آب خام و تصفيه خانهها محسوب مىشوند، منابع آب زيرزمينى و آب آشاميدنى تصفيه شده شرق تهران از نظر كيفى نسبت به استامينوفن و ايبويروفن ايمن محسوب مىشوند.

كلمات كليدى: آب خام، استامينوفن، ايبويروفن، آلودگى. r_moogoui@iau-tnb.ac.ir :نويسنده مسئول" 